\title{
Mieloma multipel: aspek patogenesis molekuler
}

\author{
I Made Bakta
}

1 Crossref Crossmark DOI : 10.36216/jpd.v3i1.70

Divisi Hematologi dan Onkologi Medik Departemen Penyakit Dalam Fakultas Kedokteran Universitas Udayana/ Rumah Sakit Umum Pusat Sanglah Denpasar
Diterima: 4 Januari 2019

Disetujui: 6 Januari 2019

Diterbitkan: 7 Januari 2019
Multiple myeloma (MM) is a neoplastic plasma disorder that is characterized by clonal proliferation of malignant plasma cells in the bone marrow, monoclonal protein in the blood or urine and associated organ dysfunction. It is preceded by a premalignant tumor which is share genetic abnormalities, monoclonal gammopathy of undetermined significance (MGUS). Although remarkable progress has been achieved, but pathogenesis of MM is still very complex. Multiple myeloma appears to arise from the malignant transformation of germinal-center B-lymphocyte. The first oncogenic events in MM appear to occur in the germinal center due to error in isotype class switching and somatic hypermutation. MM is divided into two distinct genetic subtypes: (1) hyperdiploid myeloma is characterized by multiple trisomies of chromosome 3, 5, 7, 9, 11, 15, 19 and 21; (2) non-hyperdiploid in contrast is characterized by recurrence translocations $t(4 ; 14), t(14 ; 16), t(14 ; 20) ; t(6 ; 14)$ and $t(11 ; 14)$. A unifying event in the pathogenesis of $M M$ is the dysregulated expression of cyclin D gene. Genetic aberrations occur in MM and also in premalignant state (MGUS), suggesting that genetic mutations alone are necessary, but not sufficient for myeloma transformation. A "random second hit model" was proposed. Hypothetical second hits are: additional genetic changes (RAS mutation, p16 methylation, p53 mutation), proliferation due to cell cycle dysregulation, evasion of programmed cell death and changes in bone marrow microenvironment. A complex interaction with the bone marrow microenvironment, characterized by activation of osteoclast and supression of osteoblast, leads to lytic bone lesions.

Keywords: multiple myeloma, pathogenesis, molecular

\section{PENDAHULUAN}

Mieloma multipel atau "multiple myeloma" (MM) adalah kelainan neoplastik sel plasma yang ditandai oleh proliferasi klonal sel plasma maligna dalam lingkungan mikro sumsum tulang, dengan manifestasi berupa protein monoklonal dalam darah dan urine serta disfungsi organ. Mieloma multipel merupakan jenis ketiga dari keganasan hematologik utama, setelah limfoma dan leukemia. MM merupakan 1\% dari seluruh keganasan dan 13\% dari keganasan hematologik. Insidennya di negara Barat adalah 5,6 per 100.000 penduduk per tahun. MM lebih banyak dijumpai pada umur lanjut dengan umur rata-rata 70 tahun. Sekitar 37\% penderita berumur kurang dari 65 tahun, 26\% di antara umur 65 sampai 74 tahun, dan $37 \%$ berumur 75 tahun atau lebih. ${ }^{1,2}$

Perkembangan pengetahuan tentang patogenesis MM terutama dari aspek molekuler terjadi dengan cepat dalam empat dekade ini, namun demikian masih banyak halhal yang belum diketahui. Perkembangan patogenesis ini menunjang perkembangan terapi MM. Telah dikembangkan berbagai obat untuk menghambat angiogenesis, memodulasi respon imun dan tergeted therapy terhadap berbagai molekul yang berperan dalam patogenesis MM. Semula hanya dipakai melphalan, kemudian dipakai thalidomide, lenalidomid, dan obat imimunomodulator lainnya, terakhir dipakai bortezomid dan carpilzomib, yang merupakan suatu proteasome inhibitor. Harapan hidup penderita memanjang dari hanya 2 tahun menjadi 8 sampai 10 tahun. Harapan hidup 10 tahun bagi penderita MM berumur kurang dari 60 tahun saat ini adalah 30\%. Namun demikian harapan hidup jangka panjang penderita masih lebih rendah dibandingkan dengan harapan hidup keganasan hematologik lainnya. ${ }^{1,2}$

\section{TAHAP PERJALANAN PENYAKIT MIELOMA MULTIPEL}

Multipel mieloma mempunyai tiga tahap perjalanan penyakit:

1. Monoclonal gammopathy of undetermined significance (MGUS)

2. Smoldering Multiple Myeloma (SMM)

3. Multiple Myeloma (MM) 
MM timbul dari mutasi klonal satu sel limfosit B, clonal plasma cells (PCs) harus berkembang mendekati $10^{9}$ untuk dapat menghasilkan monoclonal Ig (M-Ig) supaya dapat dideteksi dengan serum electrophoresis. ${ }^{3}$ MGUS adalah tahap pertama perkembangan perjalanan penyakit MM, suatu tumor premaligna yang dapat berkembang menjadi MM. MGUS dijumpai pada 1\% dari penduduk normal berusia di atas 25 tahun dan 3\% pada penduduk berusia di atas 70 tahun. MGUS berkembang menjadi MM dengan kecepatan $1 \%$ per tahun. Hampir semua MM didahului oleh MGUS.,5 MGUS dibedakan dengan MM karena pada MGUS protein monoklonal $(M-s p i k e)<30 \mathrm{~g} / \mathrm{L}$, tidak disertai kerusakan end organ (asimtomatik), dan jumlah sel plasma dalam sumsum tulang $<10 \%{ }^{5}$

Smoldering Multiple Myeloma (SMM) sudah bersifat maligna, merupakan perkembangan dari MGUS. Disini $M$-spike $>30 \mathrm{~g} / \mathrm{L}$, jumlah sel plasma dalam sumsum tulang $>10 \%$, tetapi belum ada kerusakan end organ. ${ }^{5}$ Pada tahap terakhir terjadilah Multiple Myeloma (MM) yang ditandai oleh $M$-spike $>30 \mathrm{~g} / \mathrm{L}$, sel plasma dalam sumsum tulang $>10 \%$ dan sudah terjadi kerusakan end organ. Kerusakan end organ pada MM dikenal sebagai $C R A B$ (calcium, renal, anemia, bone). Disini terjadi hiperkalsemia (>12 mg/dl) karena terjadinya kerusakan tulang akibat pengaruh osteoklas berlebihan. Kerusakan ginjal (renal disease) terjadi karena deposit $M$-protein pada ginjal, infeksi dan hiperkalsemia. Anemia merupakan gejala yang sangat sering dijumpai karena adanya pendesakan sistem eritroid oleh sel plasma dan juga akibat berbagai sitokin (IL-6 dan TNF-alpha). Kerusakan tulang (bone lesion), khas berbentuk lesi osteolitik disebabkan karena aktivitas osteoklas berlebihan., ${ }^{2,6}$ Extramedullary MM merupakan tumor yang lebih agresif, sering disebut PCL (plasma cell leukemia) primer atau sekunder. ${ }^{3}$ Tahapan perjalanan penyakit MM dapat dilihat pada Gambar 1.

Perubahan molekuler apa yang menyebabkan evolusi dari MGUS menjadi SMM dan MM belum diktehui dengan pasti. Dihipotesiskan bahwa instabilitas genetik serta perubahan lingkungan mikro sumsum tulang merupakan determinan utama evolusi ini. Karakteristik intrinsik clone sel MGUS, khususnya adalah abnormalitas sitogenetik dan/ atau aneuploidy DNA, produksi dari isotipe imunoglobulin non-Ig, protein monoklonal dalam darah lebih dari $1,5 \mathrm{~g} / \mathrm{L}$, merupakan prediktor progresi MM. Infiltrasi sumsum tulang oleh sel mieloma lebih dari 5\%, adanya sel plasma beredar dalam darah, dan supresi sel plasma poliklonal dalam sumsum tulang juga mempunyai nilai prediksi terhadap transformasi maligna. ${ }^{4}$

\section{ASAL-USUL SEL GANAS PADA MIELOMA MULTIPEL}

MM adalah keganasan limfosit B. Sel induk hematopoietik (hematopoietic stem cell) akan berkembang menjadi sel induk mieloid dan sel induk limfoid. Sel induk limfoid menghasilkan sel limfosit dalam sumsum tulang yang perkembangannya tidak tergantung antigen (antigenindependent), kemudian beredar dalam darah sebagai "naive lymphocyte". Apabila mengalami pemaparan antigen maka akan mengalami perkembangan tahap kedua yang tergantung antigen (antigen-dependent) kemudian berpindah ke kelenjar

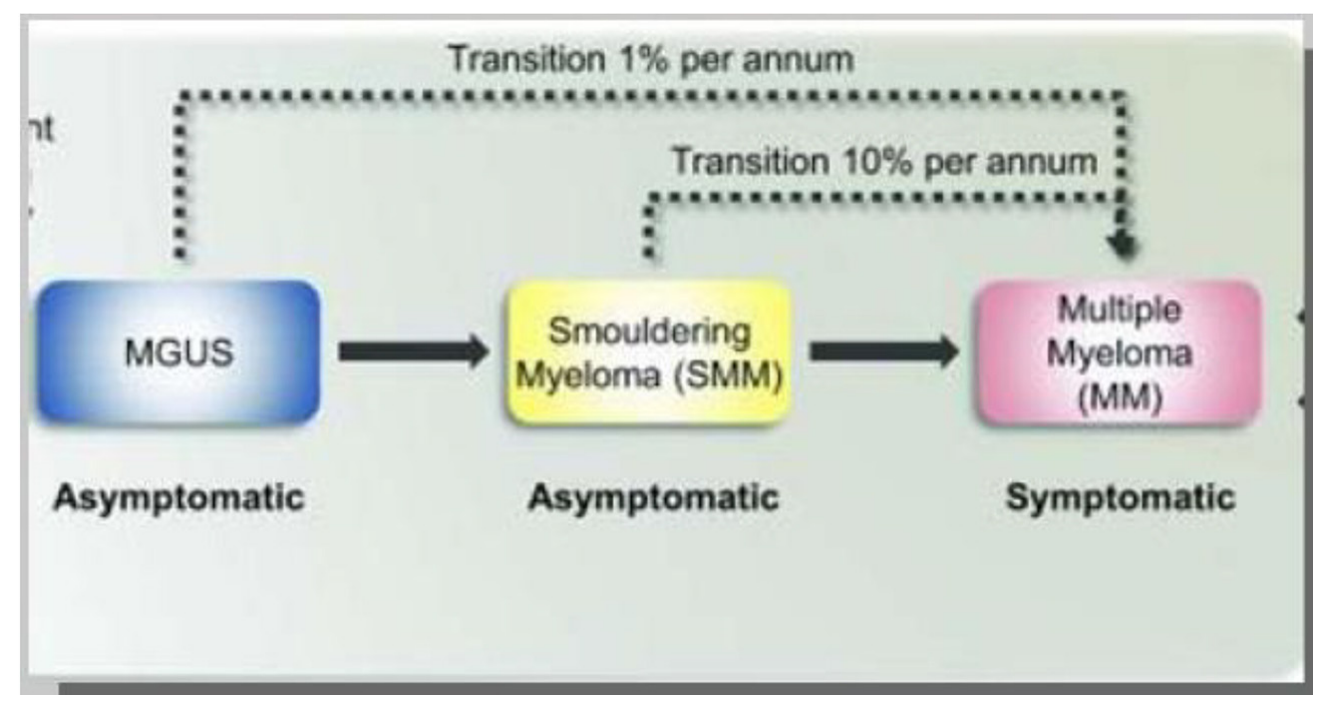

Gambar 1. Tahap perkembangan dari MGUS, SMM menjadi MM (Dikutip dari: Cogbill CH. Molecular Diagnostics of Multiple Myeloma. www.wmc./Molecular-DiagnosticsMultiple-Myeloma) 
getah bening. Limfosit dalam kelenjar getah bening masuk ke dalam Germinal Centre (GC), mengalami beberapa ronde somatic hypermutation (SHM) dan IgH (immunoglobulin heavy chain) class switch recombination (CSR). Limfosit B yang sebelumnya hanya menghasilkan imunoglobulin-M (IgM), setelah isotype switching sebagai besar menghasilkan IgG dan IgA. Limfosit yang mengalami seleksi positif akan berkembang menjadi "long-lived PCS (sel plasma yang berumur panjang), menjadi sel memori atau sel plasma yang akan bermigrasi kembali ke dalam sumsum tulang dan berakhir sebagai sel plasma yang dapat menghasilkan antibodi sesuai dengan antigen yang masuk (Jaganath). 5,6,8

Penemuan terakhir menyatakan bahwa MGUS, SMM dan MM berasal dari "post germinal centre " (post-GC) $B$-lymphocyte, yang mengalami kesalahan dalam proses fisiologik SHM dan CSR sehingga terjadi suatu mutasi neoplastik. Sel ini menjadi apa yang disebut "long-live PCs", sel plasma yang hidup dalam waktu panjang, yang sangat tergantung pada lingkungan mikro sumsum tulang. Sel plasma (plasma cells = $P C s)$ normal mempunyai $\mathrm{CD} 38^{+}, \mathrm{CD} 138^{+}, \mathrm{CD} 19^{+}, \mathrm{CD} 45^{+}$dan CD56, sedangkan PCs dari MGUS, SMM dan MM adalah $\mathrm{CD}^{+} 8^{+}, \mathrm{CD} 138^{-}, \mathrm{CD} 19^{+}, \mathrm{CD}^{4} 5^{+}$dan CD19- serta CD45- Faktor apa yang menyebabkan perbedaan imunofenotipe ini belum diketahui dengan pasti. ${ }^{6}$ Sel mieloma (patologik) berbeda dengan sel plasma normal, dimana sel mieloma mempunyai kemampuan proliferasi, meskipun terbatas.

\section{PATHOGENESIS MOLEKULER DARI MIELOMA MULTIPEL.}

Pathogenesis mieloma multipel mempunyai dua komponen utama:

1. Perubahan neoplastik dalam sel plasma (PCs) sendiri.

2. Perubahan lingkungan mikro (microenvironment) dalam sumsum tulang yang sangat mempengaruhi pertumbuhan sel ganas.

Dasar pathogenesis MM adalah perubahan genetik yang bersifat multistep pada limfosit B dan perubahan lingkungan mikro (microenvironment) sumsum tulang. ${ }^{1}$

Perubahan genetik awal pada MM adalah translokasi kromosom yang terjadi pada "immunoglobulin switch region" pada kromosom 14 (q32,33), yang sering sekali mendekat (juxtaposition) pada MAF (t[14,16][q32.33;23]) dan MMSET pada kromosom 4p16.3. Proses ini mengakibatkan disregulasi dari dua gen yang berdekatan yaitu MMSET pada semua kasus dan FGFR3 pada 30\% kasus. Secondary late-onset translocations dan mutasi gen yang berakibat progresi penyakit meliputi abnormalitas karyotipik yang kompleks pada MYC, aktivasi NRAS dan KRAS, mutasi pada FGFR3 dan TP 53, serta inaktivasi "cyclic-dependent inhibitor" CDKN2A dan CDKN2C. Perubahan genetik lainnya meliputi disregulasi epigenetik seperti misalnya perubahan ekspresi microRNA, modifikasi methylasi gen, global hyperpemethylation dan hypermethylation dari target genes. ${ }^{1}$

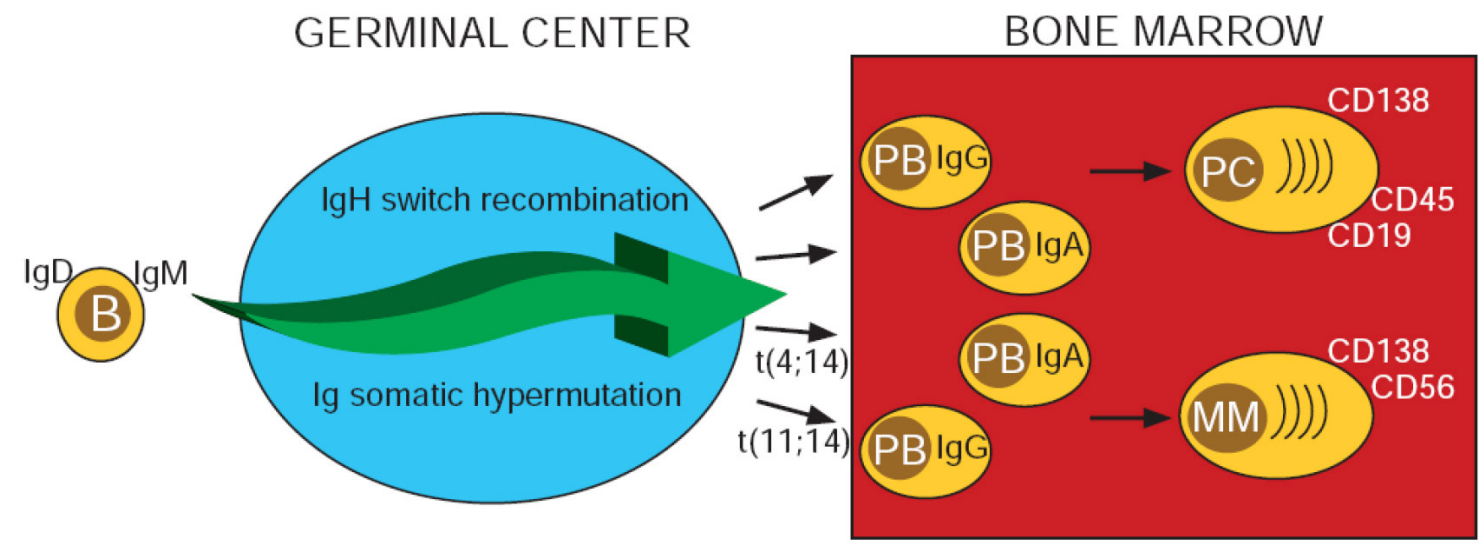

Gambar 2. Perkembangan limfosit menjadi sel plasma normal dan maligna (dikutip dari Bergagsel et al, Wintrobe's Clinical Hematology, 2014) ${ }^{6}$

Keterangan Gambar:

Sel Pre GC yang mengekspresikan imunoglobulin permukaan (IgM dan IgD) memasuki germinal centre (GC) mengalami beberapa ronde somatic hypermutation (SHM) diikuti oleh IgH isotype class switch recombination (CSR). Dalam keadaan normal limfosit B yang berhasil melewati fase ini akan menjadi "lomg-live PCs" kemudian bermigrasi kembali ke sumsum tulang menjadi sel fungsional. Pada MM, translokasi IgH terjadi disertai kesalahan SHM dan CSR. ${ }^{5}$ Perubahan-perubahan tersebut mengaktifkan onkogen seperti K-RAS dan N-RAS, MYC, PI3K, AKT, BRAF, serta menekan fungsi supressor genes seperti tumor protein 53 dan retinoblastoma 1, terjadi mutasi neoplastik menjadi sel mieloma 
Secara genetik terdapat dua subtipe perubahan: (1) subtipe satu yang ditandai oleh translokasi gen imunoglobulin berulang (recurrent immunoglobulin translocations) yang meliputi lima lokus (4p16 FGFR3/MMSET, 16q23 c-maf, 20q11mafB, 11q13 CCNDI, 6p21 CCND3); dan (2) subtipe tanpa translokasi, yang ditandai oleh hiperdiploidi multiple trisomies dari kromosom ganjil 3, 5, 7, 9, 11, 15, 19 dan 21 . Perubahan genetik sekunder yang dijumpai pada kedua subtipe MM meliputi mutasi aktivasi ras, mutasi inaktivasi p53 dan translokasi $m y c^{3,9}$

Perubahan genetik menyebabkan perubahan ekspresi molekul adhesi pada permukaan sel mieloma dan juga respon terhadap stimulus pertumbuhan (growth stimuli) dalam lingkungan mikro sumsum tulang. Semua ini akan menimbulkan peristiwa biologik, baik pada sel tumor seperti: proliferasi, migrasi serta berkurangnya apoptosis dan DNA repair maupun pada perubahan lingkungan mikro sumsum tulang. ${ }^{4}$

Pada MGUS, SMM dan MM dijumpai translokasi kromosom yang melibatkan IgH locus (14q32) atau satu dari IgL loci (kappa, 2p12, atau lambda, 22q11). Perubahan ini terjadi karena kesalahan Immunoglobuline switch recombination atau SHM. Perubahan ini tidak pernah dijumpai pada sel plasma normal, oleh karena itu sangat mungkin translokasi ini merupakan peristiwa onkogenik primer, mungkin merupakan "initiating event" dari perubahan onkogenik pada waktu limfosit melewati "germinal centre". Translokasi ini mengakibatkan disregulasi atau peningkatan ekspresi onkogen yang berposisi dekat IgH enhancer yang kuat. Terdapat tiga grup translokasi IgH yang berulang yaitu: CYCLIN D (15\%), CYCLIN D2 < $15 \%$, MAF $5 \%$, MAFB $2 \%$, MAFA $<1 \%$.
Semua perubahan - perubahan tersebut dapat dijumpai pada MGUS, SMM maupun MM, berarti ini adalah perubahan awal (initiating events). Supaya dapat berkembang lebih lanjut memerlukan perubahan-perubahan tambahan, seperti digambarkan oleh Bianchi dan Munshi ${ }^{4}$ pada Gambar 3.

Oleh karena tidak semua kasus MGUS menjadi MM, ini berarti initial genetic events pada sel MGUS memang diperlukan tetapi tidak cukup untuk menimbulkan MM. Perubahan dari MGUS menuju MM bersifat random, sehingga dikembangkan teori "random second hit model". ${ }^{10}$ Berbagai hal yang merupakan second hit yang menyebabkan progresi menuju MM adalah: ${ }^{10}$

1. Perubahan genetik tambahan (seperti RAS mutation, p16 methylation, p53 mutations)

2. Meningkatnya proliferasi sel karena cell cycle dysregulation.

3. Evasi dari programmed cell death (apoptosis)

4. Perubahan dalam lingkungan mikro sumsum tulang.

Perubahan genetik tambahan dapat berupa translokasi IgH, delesi pada $17 \mathrm{p} 13$ serta mutasi Ras genes. Secondary IgH translocations meliputi MYC oncogenes (8q24). Mutasi $N$ \& K Ras yang berfungsi dalam regulasi proliferasi dan diferensiasi sel, jika mengalami mutasi dapat bekerja sebagai onkogen yang kuat. Pada MM juga terjadi aktivasi NF kappa, suatu faktor transkripsi yang mengatur proliferasi sel. Disregulasi siklus sel (cell cycle dysregulation) memegang peran penting dalam patogenesis MM. Perubahan dalam regulasi siklus sel terjadi dalam bentuk: $:^{10,11}$

1. Overekspresi cyclin D1, cyclin D2 atau cyclin D3 melalui translokasi immunoglobuline heavy chain $(\mathrm{IgH})$ locus.

2. Hilangnya cyclin D kinase inhibitors (Cdkl)

Lymph Node

\section{Bone Marrow}

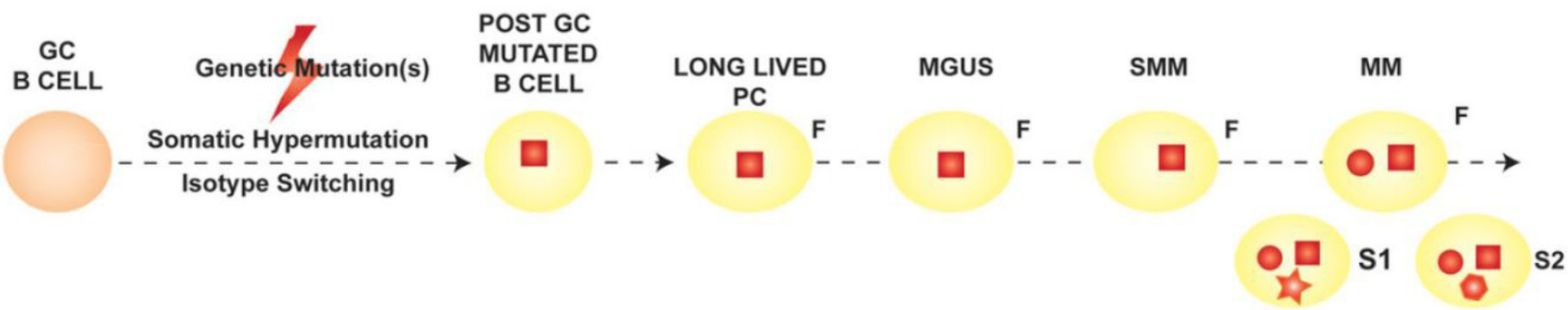

Gambar 3 Perjalanan pathogenesis dari mieloma multipel (Dikutip dari: '.Bianchi G, Munshi NC. Pathogenesis beyond the cancer clone(s)in multiple myeloma. Blood 2015;125:3049-3056). ${ }^{4}$

Keterangan gambar:

Sel bulat oranye menunjukkan limfosit B normal, sedangkan sel bulat kuning adalah limfosit B post-GC yang mengalami mutasi kemudian berdiferensiasi menjadi long-lived PC (plasma cell) (sel kuning oval). Pada patogenesis MM, peristiwa genetik awal (segi empat merah) terjadi di germinal centre $(G C)$ difasilitasi oleh proses somatic hypermutation dan isotype switching, yang dijumpai pada kelompok sel (clone) yang akan menjadi MM. Terjadi mutasi genetik lanjutan (ditandai oleh bulatan merah) dengan mutasi baru (de novo) (ditandai oleh bentukan geometrik merah) dijumpai selama evolusi penyakit, terdapat secara heterogen pada subclone (S1 dan S2).4 
3. Inaktivasi gen Cdkl oleh hipermetilasi.

Pada MM terjadi disregulasi dari apoptosis sehingga jumlah sel ganas terus bertambah. Berkurangnya apoptosis dapat disebabkan karena: ${ }^{10}$

1. Interleukin-6 (IL-6) suatu sitokin yang meningkatkan pertumbuhan sel plasma dan melepaskan diri dari apoptosis

2. Meningkatnya ekspresi protein anti-apoptotik Bcl-2 yang dijumpai pada sebagian besar kasus MM

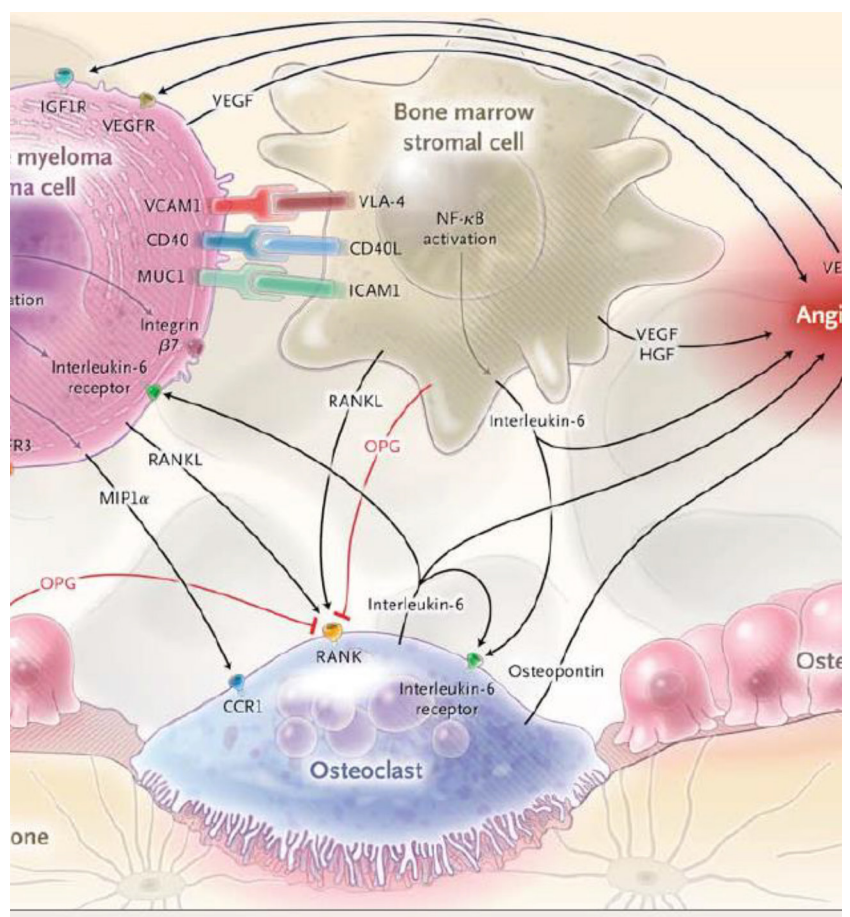

Gambar 4. Interaksi lingkungan mkiro sumsum tulang dengan sel plasma (dikutip dari Palumbo et al., $N$ Engl J Med 2011;364:1046) ${ }^{1}$

Keterangan gambar:

Adhesi antara sel plasma dengan sel stroma dimediasi oleh "celladhsesion molcules", seperti VCAM1 (vascular-cell adhesion molecule 1) dan integrin alpha (VLA-4). Interaksi ini meningkatkan sekresi growth factors, seperti IL-6 dan VEGF (vascular endothelial gowth factor) dengan akibat proliferasi sel plasma dan angiogenesis. Peningkatan aktivitas osteoklas terjadi karena ketidak-seimbangan rasio antara RANK (receptor activator of nuclear faktor kappa B dan osteoprotegerin $(O P G)$ karena peningkatan produksi RANKL (RANK-ligand) dan berkurangnya produksi OPG. Aktivitas osteoblas disupresi oleh produksi dickkofp homolog 1(DKK1) oleh sel plasma. Sel plasma dapat menghambat osteoblas melalui suatu faktor transkripsi, runt-related transcription factor 2, yang mengurangi diferensiasi dari prekursor osteoblas menjadi osteoblas matur. Adhesi sel plasma pada sel stroma meningkatkan berbagai sitokin dengan aktivitas angiogenesis, terutama IL-6 dan VEGF. Osteoklas yang diaktifkan oleh sel stroma menimbulkan angiogenesis yang berkelanjutan karena karena sekresi osteopontin.
3. Sekitar 65\% kasus MM menunjukkan hipermetilasi dari promoter of death associated protein (DAP) kinase yang mengatur apoptosis.

\section{PERUBAHAN PADA LINGKUNGAN MIKRO SUMSUM TULANG}

Berbagai perubahan pada lingkungan mikro (microenvironment) sumsum tulang terjadi yang menyebabkan proliferasi sel plasma abnormal dan progresi dari MGUS ke MM adalah: ${ }^{10,12,13,14}$

1. Induksi angiogenesis

2. Supresi imunitas seluler (cell-mediated immunity)

3. Paracrine loops yang melibatkan interleukin-6 dan vascular endothelial growth factor (VEGF)

4. Modulasi pertumbuhan tumor oleh stromal-cell-derived exosomes sumsum tulang.

Terjadi interaksi yang sangat intensif antara sel plasma dengan sel-sel pada sumsum tulang seperti yang digambarkan oleh Palumbo et al., ${ }^{1}$ seperti dapat dalam dalam Gambar 4.

Sitokin IL-6 dibuat oleh berbagai jenis sel. Stimuli luar seperti hipoksia dan sinyal internal akibat disregulasi MYC, menstimulir sekresi HIF- $\alpha$ dan VEGF kemudian menstimulir sel endotel untuk mensekresi IGF-1. Lesi tulang disebabkan karena gangguan remodeling akibat ketidak seimbangan aktivitas osteoclas (yang dimediasi RANKL/RANK, penurunan osteoprotegerin (OPG) dan meningkatnya MIF$1 \alpha$ ) dan menurunnya aktivitas osteoblas (dimediasi DKK1 dan IL-3). Peningkatan aktivitas osteoklas meningkatkan survival dan pertumbuhan sel mieloma, paling sedikit karena pengaruh dari Il-6. ${ }^{11,14}$

\section{SITOKIN PADA MIELOMA MULTIPEL}

Interaksi antara sel mieloma dengan lingkungan mikro sumsum tulang menghasilkan berbagai sitokin yang mempengaruhi pertumbuhan sel ganas sekaligus dapat juga dijadikan target terapi MM..$^{10,14,15}$

a. Interleukin-6

Interleukin-6 (IL-6) dikenal sebagai B-cell growth factor dan merupakan sitokin yang paling penting menentukan proliferasi, penghindaran terhadap apoptosis dan survival sel mieloma. IL-6 bersifat pleotrofik yang mempunyai berbagai efek pada sel B, sel $\mathrm{T}$ dan sel lain. Sitokin ini bekerja pada signal-transducing protein gp130, mengaktifkan Ras/Raf/mitogen activated protein kinase (MAPK dan extracellular signal-related kinase (REK), JAK (Janus kinase), STAT (signaltransducer and activator of transcription (STAT), dan phophatidyl inositol-3 kinase (PI3-K). ${ }^{14}$

b. Vascular Endothelial Growth Factor (VEGF)

VEGF, suatu sitokin multifungsi yang memegang peran penting memicu migrasi sel tumor dan angiogenesis. Sitokin ini juga mempunyai efek moderat pada proliferasi 
sel mieloma. Adhesi sel mieloma dengan bone marrow stem cell meningkatkan sekresi VEGF dan juga karena pengaruh IL-6. Thalidomid menekan angiogenesis pada MM dengan menghambat pengaruh VEGF. ${ }^{14}$

c. Insulin - Like Growth Factor-1 (IGF-1)

IGF-1 mengaktifkan dua signalling pathway pada MM yaitu jalur MAP Kinase dan jalur PI3-K yang menyebabkan efek proliferasi dan antiapoptotik. IGF-1 juga memediasi adhesi dan migrasi sel mieloma. ${ }^{14}$

d. Tumor Necrosis Factor - Alpha (TNF- $\alpha)$

TNF- $\alpha$ mempunyai peran penting untuk fungsi, diferensiasi dan transformasi limfosit B. TNF- $\alpha$ menginduksi sekresi IL-6 oleh sel induk sumsum tulang dan juga mengaktivasi $N F-k B$, meningkatkan molekul adhesi, yang mengakibatkan adhesi sel mieloma pada sumsum tulang. ${ }^{14}$

\section{PATHOGENESIS KELAINAN TULANG PADA MIELOMA MULTIPEL}

Kelainan tulang merupakan petanda penting mieloma multipel yang dapat menurunkan kualitas hidup, serta meningkatkan morbiditas dan mortalitas penderita. Pathogenesis dasar kelainan tulang pada mieloma multipel (myeloma-related bone disease) adalah ketidak seimbangan dari proses remodelling tulang (uncoupling of the bone-remodelling process). Interaksi antara sel mieloma dengan lingkungan mikro sumsum tulang akhirnya mengaktifkan osteoklas dan menghambar osteoblas, yang menyebabkan kehilangan tulang (bone loss). Akhir-akhir ini diketahui bahwa osteosit merupakan pengatur kunci (key regulator) dari kerusakan tulang pada mieloma melalui interaksi langsung dengan sel mieloma..$^{10,13}$

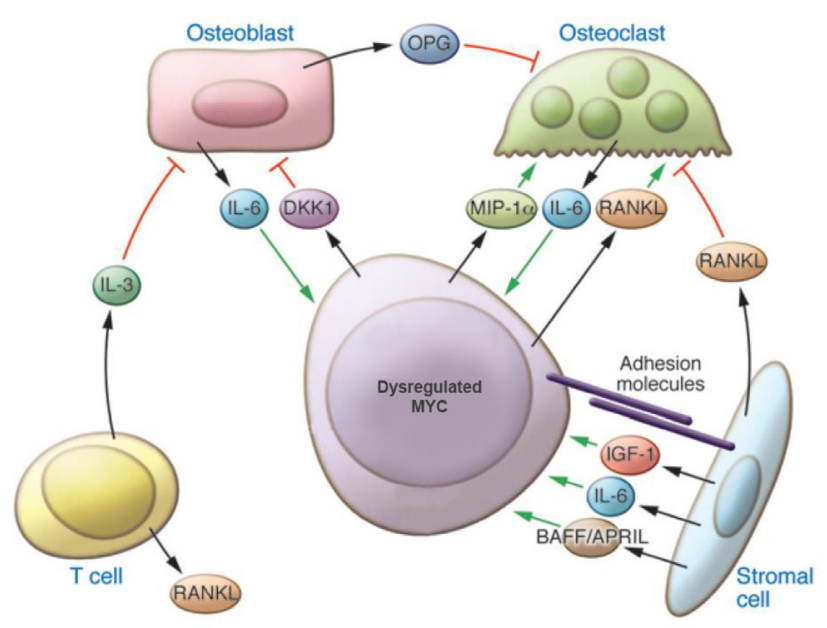

Gambar 5. Patogenesis Kelainan Tulang pada Milemoa Multipel (dikutip dan dimodifikasi dari Kuehl \& Bergagsel, J Clin Investigation 2012;122:3456) ${ }^{11}$
Skema perubahan patologik yang menyebabkan kerusakan tulang dapat dilihat pada Gambar 5. Peningkatan aktivitas osteolitik dimediasi melalui eskpresi RANKL (Receptor Activator of Nuclear Factor kappa-B Ligand) oleh osteoblas (mungkin juga oleh sel plasma), disertai dengan penurunan reseptor umpan (decoy receptor) yaitu osteoprotegerin (OPG) yang menjurus pada peningkatan rasio RANKL/OPG, sehingga meningkatkan aktivitas osteoklast dan resorpsi tulang. Peningkatan macophage inflammatory protein-1-alpha (MIP-1 alpha, CCL3), IL-3 dan IL-6 yang dihasilkan sel stroma sumsum tulang juga ikut meningkatkan aktivitas osteoklas. Terakhir, ekspresi SDF-1alpha (stromal-derived factor $1 \alpha$ ) meningkatkan aktivitas osteoklas dengan mengikat CXCR4 pada prekursor osteoklast. ${ }^{10}$ Disamping aktivasi osteoklas, terdapat supresi aktif osteoblas pada mieloma. Hal ini dihubungkan dengan kadar IL-3, IL-7 dan DKK1 (dickkopf 1) yang menghambat diferensiasi osteoblast. ${ }^{10}$ Menurut Shay $\mathrm{dkk},{ }^{12}$ faktor yang menimbulkan supresi osteoblas adalah wnt pathway dan myeloma-derived factors, seperti IL-3 dan fibroblast growth factor 23 (FGF23).

Kerusakan tulang pada MM berupa kerusakan osteolitik yang multipel pada tulang pipih: tulang tengkorak, tulang iga, pangkal humerus, tulang belakang, tulang pelvis dan pangkal dari femur, tempat dimana hematopoiesis masih aktif. Kelainan osteolitik yang besar menimbulkan nyeri tulang dan dapat menimbulkan fraktur patologik. ${ }^{2,15}$

\section{RINGKASAN}

Mieloma multipel adalah suatu kelainan sel plasma yang bersifat maligna yang merupakan 10\% dari semua keganasan hematologik yang timbul dari kelainan premaligna yaitu MGUS. MM timbul dari mutasi neoplastik limfosit B post - GC. Patogenesis MM sangat kompleks dan belum semuanya dapat diketahui. Terdapat two-step model progression: (1) terbentuknya proliferasi klonal yang terbatas yang dikenal sebagai MGUS, dimana terjadi perubahan genetik (apakah translokasi IgH atau hiperdiploidi) sebagai produk dari stimulasi antigenik; (2) suatu peristiwa kedua (second hit) yang terjadi secara random, mengakibatkan akumulasi sel tumor dan progresi menjadi MM. Progresi ini didorong oleh perubahan genetik, perubahan epigenetik dan perubahan lingkungan mikro sumsum tulang.

\section{REFERENSI}

1. Palumbo A, Anderson K. Multiple Myeloma. N Engl J Med 2011;364:1046-1060

2. Dispenzieri A, Lacy MQ, Kumar S. Multiple Myaloma. In: Greer JP, Arber DA, Glader B, List A, Means RT, Paraskevas, Rodgers GM (editors). Wintrobe Clinical Hematology. Thirteen edition. Philadelphia: Lippincott, 


\section{EDITORIAL}

Jurnal Penyakit Dalam Udayana

Udayana Journal of Internal Medicine

Volume 3, No 1: 2019

Williams \& Wilkins, 2014.

3. Bergagsel PL, Kuehl WM. Molecular Pathogenesis and a Consequent Classification of Multiple Myeloma. J Clin Oncol 2005;23:6333-6338.

4. Bianchi G, Munshi NC. Pathogenesis beyond the cancer clone(s)in multiple myeloma. Blood 2015;125:3049-3056.

5. Chesi M, Bergsagel PL. Molecular pathogenesis of multiple myeloma:basic and clinical updates. Int J Hematol 2013;97:313-323

6. Bergsagel PL, Stewart AK, Russel J, Fonseca R. Molecular genetic aspects of plasma cell disorders. In: Greer JP, Arber DA, Glader B, List A, Means RT, Paraskevas, Rodgers GM (editors). Wintrobe Clinical Hematology. Thirteen edition. Philadelphia: Lippincott, Williams \& Wilkins, 2014.

7. Cogbill CH. Molecular Diagnostics of Multiple Myeloma. www.wmc./Molecular-Diagnostics-Multiple-Myeloma. Diakses 15 April 2018

8. Jaganath S. Pathophysio;logical Underpinings of Multiple Myeloma Progression. J Manag Care Pharm 2008;14(sppl S):S7-S11

9. Bergagsel PF. Molecular Pathogenesis of Multiple Myeloma. $\quad$ www.mayoclinic.pure.elsevier.com/ molecular-pathogenesis- multiple- myeloma. Diakses 15 April 2018
10. Rajkumar SV/ Pathobiology of Multiple Myeloma UpToDate. www.uptadate.com/contents/pathobiologyof-multiple myeloma. Last updated Nov 23, 2017.

11. Kuehl WM, Bergsagel PL. Molecular pathogenesis of multiple myeloma and its premalignant precursors. J Clin Investig 2012;122:3456-3463.

12. Shay G, Hazlehurst L, Lynch CC. Dissecting the Multiple Myeloma-bone microenvironment reveals new therapeutic opportunities. J Mol Med (Berlin) 2016;94:2125,

13. Terpo E, Stathopoulos IN, Gavriatopoulou M, Dimepoulos MA. Pathogenesis of bone disease in multiple myeloma: from bench to bedside. Blood Cancer Journal 208;8:1-12

14. Kalita LKK, Saikia B. Recent advances in molecular pathogenesis of multiple myeloma - Role of cytokine: Review of literature. Int J Med Health Res 2016;2:43-45

15. Anderson KC. Progress and Paradigms in Multiple Myeloma. Clin Cancer Res 2016; 22:5419-5427.

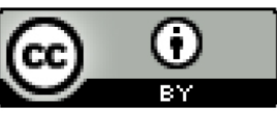

This work is licensed under a Creative Commons Attribution 4.0 International License. 